\title{
Vocational Students' Perceptions of Mobile Assisted Language Learning (MALL) Materials
}

\author{
Helena Octavia ${ }^{1}$, Utami Widiati ${ }^{1}$, Enny Irawati ${ }^{1}$ \\ ${ }^{1}$ Postgraduate Student at Universitas Negeri Malang
}

\begin{tabular}{l}
\hline INFO ARTIKEL \\
\hline Riwayat Artikel: \\
Diterima: $21-06-2019$ \\
Disetujui: 18-10-2019 \\
\hline Kata kunci: \\
vocational student; \\
students' perceptions; \\
mobile assisted language learning
\end{tabular}

\section{Alamat Korespondensi:}

Helena Octavia

Pendidikan Bahasa Inggris

Universitas Negeri Malang

Jalan Semarang 5 Malang

E-mail: helenasihombing70@gmail.com

\begin{abstract}
ABSTRAK
Abstract: Digital resources have been proven able to assist English language learners in improving their interaction skills, widening their vocabulary range, and enhancing their reading comprehension. Despite their benefits, digital tools can also create distractions for students. This article reports on the result of a survey to 150 vocational students on Mobile Assisted Language Learning (MALL) materials. The students agreed that MALL materials were more authentic (67\%) and more accessible (59\%) than traditional learning materials. The use of MALL materials could trigger classroom interactions (64\%) and facilitated learning (56\%). The implementation of MALL materials allowed students to get immediate feedback from the teachers $(73 \%)$.

Abstrak: Sumber daya digital telah terbukti dapat membantu pelajar bahasa Inggris dalam meningkatkan keterampilan interaksi, memperluas jangkauan kosa kata, dan meningkatkan pemahaman bacaan mereka. Selain bermanfaat, alat digital juga dapat menggangu proses belajar. Artikel ini melaporkan hasil survei terhadap 150 siswa kejuruan terkait dengan implementasi materi berbasis gawai atau Mobile Assisted Language Learning (MALL). Ditemukan bahwa siswa sepakat bahwa materi MALL lebih otentik (67\%) dan lebih mudah diakses (59\%) daripada materi pembelajaran tradisional. Penggunaan MALL dapat memicu interaksi kelas (64\%) dan memfasilitasi pembelajaran (56\%). Dengan menerapkan materi berbasis gawai atau MALL materials di kelas, para siswa mengakui bahwa mereka bisa mendapatkan umpan balik langsung dari para guru $(73 \%)$.
\end{abstract}

Digital resources have been proven able to assist English language learners in improving their interaction skills, widening their vocabulary range, and enhancing their reading comprehension (Patten \& Craig, 2007). Given access to the internet and social media, students can also promote their intercultural skills and global awareness. As suggested by Warschauer and Healey (1998, as cited in Brown, 2001, p.145), the integration of digital technologies into an English language classroom has great potential to accommodate individualization in big classes, multimodal practice, collaborative and fun learning activities. Therefore, the interest of using computers for language teaching and learning has been maintained.

Until the last two decades, the most recent manifestation of Computer Assisted Language Learning (CALL) has become more popular (Burston, 2014). People started to integrate mobile devices into language learning. Mobile Assisted Language Learning (MALL), the most recent manifestation of CALL (Davie, 2015), has existed to support digital learning ever since. The advantages of mobile learning (m-learning) have been reported by some researchers. MALL which includes all formal and informal language learning mediated via handled devices, such as mobile phone, tablets and laptops (KukulskaHulmes \& Shield, 2007) provide educators with a lot of opportunities to encourage learning inside and outside classroom (Martin \& Ertzberger, 2013). Due to mobile convenient portability, it, therefore, allows formal and formal learning to take place anywhere (Saran et al., 2009) and anytime (Motiwalla, 2007). As a result, mobile learning can promote learners' autonomy and communication (Sato et al., 2015; Foomani \& Hidayati, 2016; Tayan, 2017).

The use of mobile devices begins to go global, especially among young people (Franklin, 2011). However, MALL in particular, has been implemented in various contexts of learning which involve learners from different age groups. Parents of five/six year-old children may not be too supportive because of their unpreparedness to assist the children in learning using mobile devices, the teachers seem very enthusiastic about implementing MALL in a language classroom (Sadykova, et al., 2016) though their positive attitudes are still lower than that of secondary school teachers (Baek, Zhang, \& Yun, 2017) 
Despite the benefits, the shortcoming of integrating mobile devices into classroom has also been noticed. Students may find MALL tasks enjoyable (Davie \& Hilber, 2015), but they felt that paper-based tasks gave more contribution to their learning (Calabrich, 2016). Even though the use of mobile technology in the classroom could make learning more realistic, the students admitted that they still needed a help in navigating their knowledge because sometimes when asked to share information with unknown internet users (if learning involved internet), they felt insecure. This, as a result, may hinder learning and encourage scepticism among learners.

Another thing that has to be considered before bringing mobile devices to the classroom is that they may create distractions and interruptions for students (Martin \& Ertzberger, 2013). Not to mention, limited battery lives of mobile devices can be also problematic (Şad \& Göktaş, 2013). Though it may be possible to prevent this problem by providing each classroom with a number of electrical plugs and sockets for all students, but the high cost should be taken into account especially in developing countries (Hockly, 2013).

The investigation should continue as Van de Vyver (2016) suggested that deeper analyses of teachers as well as students perceptions of MALL will lead to the identification of the most influential factors that affect the use of mobile devices in a language classroom. The results of a preliminary showed that almost one hundred percent of vocational students had a gadget. Some of them were able to identify and use useful features of their gadgets to help them study (e.g. dictionary) while some others were a mere user of chatting applications or browsers. These findings suggested that the implementation of MALL should also consider the ability of the students to identify helpful features of their gadgets and it should also take the students' needs and opinions into consideration.

Furthermore, it is also necessary to look at cultural specifications of the contexts where MALL is implemented. Drawing upon these conclusions and suggestions, therefore, the present research would attempt to investigate vocational high school students' perceptions of MALL. Taking into account Indonesia as a developing country which may face problems related to MALL cost, vocational school teachers who were mostly born before the digital natives era began, and Indonesian most recent curriculum which requires learning to promote digital literacy, this study is worth conducting.

\section{METHODS}

The present study was aimed to investigate vocational students' perceptions of Mobile Assisted Language Learning (MALL). It therefore attempted to examine students' opinions and experiences in integrating the use of mobile technology in the classroom. A survey was conducted to collect data students' perceptions of using mobile devices in vocational classrooms. It was then followed by a semi-structured interview to broaden understanding on what the students thought about mobile assisted language learning (MALL).

The first phase of the study was a survey. The survey participants were selected based on the purposive sampling method suggested by Palys (2008), that is to strategically choose samples based on research objectives. The purpose of this study was to reveal students' perceptions of the implementation of MALL in vocational high schools so that before selecting the participants, an observation was conducted. The result of the observation showed that there were more or less 13 public vocational high schools (SMKN) in Malang and 3 public Vocational High Schools in Batu city currently applied Mobile Assisted Language Learning (MALL) in the classrooms. Therefore, these schools were determined as places where this study was conducted and 150 vocational high school students were involved to participate in the current study. The majority of the vocational high school students' were majoring in tourism, engineering, accounting, and health.

The second phase was an interview. This interview was undertaken to dig deeper data related to the results of the questionnaire distributed earlier. Interviews participants were selected from the same group of students. After ensuring their voluntary participation for the second phase, there were five students invited to do the interviews.

Data on students' perceptions was collected using a questionnaire adapted from Dashtestani (2013). This questionnaire was distributed to the participants directly and the data was obtained during the period of two months (August $25^{\text {th }}-$ October $\left.25^{\text {th }}, 2018\right)$. Following the survey, interviews were performed to five representatives of the students. An interview guideline was developed to collect information on the students' experiences in using digital learning tools in the classroom. The interview blueprint can be seen in table 1 .

Table 1. Blueprint of Students' Questionnaire

\begin{tabular}{lll}
\hline Indicators & Sub Indicators & Items \\
& & \\
\hline MALL materials & The characteristics of MALL materials & $2,3,4,5$ \\
& The development of MALL materials by the teachers & 1,7 \\
& The use of MALL materials & 8,9 \\
\hline
\end{tabular}

There were three important steps in analyzing the questionnaire responses (Wang, 2009). After gathering data, questionnaire responses were tabulated, results were analyzed, and findings were presented. The questionnaire included responses such as strongly disagree, disagree, agree, and strongly agree. Data were then presented in percentages. 
In order to make data more meaningful, Gay et al. (2009) suggests to cluster tabulated results into groups based on research questions and objectives. The tabulations were explained related to the specifics of the study. The findings, thus, were described under three themes, including students' perceptions of the characteristics of MALL materials, of the development of MALL materials by the teachers, and the use of MALL materials in English classrooms. The results of the interviews analysis were reported based on content analysis and themes related to MALL (These themes were categorized into the role of MALL materials, the use of MALL materials, and the development of MALL materials.

\section{RESULTS}

Students' perceptions of MALL were acquired from a questionnaire consisting of seven statements (Table 1). The questionnaire was translated into Bahasa before it was distributed to the students. The Indonesian version of the questionnaire was validated by a Bahasa Indonesia teacher and ready for data collection after revision. The vocational students' perceptions of MALL were summarized in table 2.

Table 2. Students' Perceptions of MALL Materials

\begin{tabular}{|c|c|c|c|c|c|}
\hline \multirow{3}{*}{ No } & \multirow{3}{*}{ Statement } & \multicolumn{4}{|c|}{ Responses } \\
\hline & & $\begin{array}{l}\text { Strongly } \\
\text { Disagree }\end{array}$ & Disagree & Agree & $\begin{array}{c}\text { Strongly } \\
\text { Agree }\end{array}$ \\
\hline & & 4 & 3 & 2 & 1 \\
\hline \multirow[t]{2}{*}{1} & EFL teachers should be able to develop MALL materials for their & $0 \%$ & $4 \%$ & $60 \%$ & $36 \%$ \\
\hline & teaching. & $1 \%$ & $17 \%$ & $67 \%$ & $15 \%$ \\
\hline 2 & MALL materials are more authentic than traditional EFL materials. & $1 \%$ & $15 \%$ & $64 \%$ & $20 \%$ \\
\hline 3 & The use of MALL materials encourages interaction in EFL classrooms. & $0 \%$ & $16 \%$ & $59 \%$ & $25 \%$ \\
\hline 4 & MALL materials are more accessible than traditional materials. & $1 \%$ & $9 \%$ & $73 \%$ & $17 \%$ \\
\hline 5 & Immediate feedback can be provided using MALL materials. & $1 \%$ & $20 \%$ & $59 \%$ & $20 \%$ \\
\hline 6 & Using MALL materials will empower learners to be more autonomous. & $1 \%$ & $6 \%$ & $56 \%$ & $37 \%$ \\
\hline 7 & The use of MALL materials facilitates language learning. & & & & \\
\hline
\end{tabular}

The table obviously shows that the majority of the students agreed to all statements provided in the questionnaire. In details, the information can be explained as follows. According to the results, the students agreed that MALL materials were more authentic $(67 \%)$ and more accessible $(59 \%)$ than traditional learning materials. The use of MALL could trigger classroom interactions (64\%) and as a result facilitated learning (56\%). By implementing MALL in the classroom, the students admitted that they could get immediate feedback from the teacher $(73 \%)$.

\section{Students' Experiences During the Implementation of MALL Materials}

According to five students interviewed, the role of MALL materials in the classroom was significant. They agreed that MALL materials were able to help a learner study a language better, ease the learning process, and make it fun and effective since the materials could be accessed from everywhere at anytime. For example, one of the interviewees described her experience in using MALL:

Make it easier for us because we can find out a lot of references that we didn't get at school. So, we can know widely, and it's flexible too, because it saves more time and we can access the internet from anywhere. (Student no. 5, female)

Despite the benefits that may be brought by MALL materials into the classroom, one of the students showed his preference in using textbook materials rather than internet-based materials:

The role of MALL materials is quite significant, but I personally prefer textbook materials unless the presentation of the materials is attractive. (Student no. 2, male)

One of the most frequently encountered challenged to experiencing the effectiveness of MALL materials in English classroom was the internet connection. For example, a student explained his problem in using handphone to access learning materials:

Well...slow internet connection, handphone with an unsupported operating system. (Student no. 3, male)

In addition, one of the interviewees mentioned that the use of handphone in the classroom might distract students' attention from learning and thus lead to an uncontrollable behavior: 
The challenge is that the smartphone system is lacking. The bound between teacher and students is lacking too. So, the main challenge is that many students use smartphones for other things than learning English.Yes. So, I' $m$ afraid that students can be distracted from the lesson by other unnecessary things. (Student no. 6, male)

One one side, the students agreed that MALL materials could make learning more authentic because the internet provided real pictures, videos, and images that can be easily accessed by the students from everywhere. For example, a student said:

We can find pictures, videos, or power point presentations on the internet. (Student no. 3, male)

On the other hand, one of the interviewees argued that MALL materials could not make learning more authentic. It was practice that could improve students' competency in using English.

Honestly, it is a no. It only eases the process. Learning English is more into practices. If you want to be competent in writing, then you write. The VHS graduates are expected to be able to communicate with society. So, I think the authenticity of learning English lies on how to practice using the language. (Student no.6, male)

All in all, the results of the interviews suggested the students' positive attitudes towards MALL materials although there were some opinions that showed the other way around.

\section{DISCUSSION}

In the survey, the vocational school students expressed that MALL materials were authentic and more accessible than traditional learning materials. They also admitted that MALL materials could facilitate learning and trigger classroom interactions. Therefore, they believed that the implementation of MALL materials in the classroom could ease the learning process. These findings are similar to those by Davie \& Hilber (2015) which suggest that MALL materials are beneficial to improve students' motivation and have other long-term benefits which have yet to be seen. For example, Patten \& Craig (2007) argue that digital resources are able to assist English learners in improving their interaction skills. By being able to access the internet, students can promote their intercultural skills and global awareness. Therefore, the integration of digital technologies may lead to individualization, multimodal practice, and fun learning activities in big classes, such as in Indonesia.

The participants also admitted the effectiveness of the use of mobile devices in receiving feedback. They mentioned that through mobile devices, they could get immediate responses from the teachers. One of the benefits of implementing mobile learning (m-learning) is that learning can be carried out inside and outside the classroom. Learning via handled devices, such as mobile phone, tablets, and laptops provide a lot of opportunities to encourage learning from everywhere (Kukulska-Hulmes \& Shield, 2007; Saran et al., 2009; Martin \& Ertsberger, 2013) and at anytime (Motiwalla, 2007). On the contrary, Handayani, Bambang, \& Utami (2018) found that receiving immediate feedback on social media was overwhelming for students although leaving comments on someone else's posting was quite compelling. This sort of feeling later may be considered as one of the shortcomings of the integration of digital technologies into classroom. Sharing information with unknown internet users (if learning involves the internet) is able to raise uneasiness and scepticism among learners.

In addition to the benefits of MALL materials, the results of this study also reveal challenges and problems that may have been encountered by the vocational school students when using mobile phones to learn English. Slow internet connection is one of the biggest problem. Not only the connection, the students also admitted that their inability to afford sophisticated smartphones could hinder the use of MALL in learning. This finding has been confirmed by Şad \& Göktaş (2013). They argue that high cost should be anticipated before implementing MALL in the classroom, particularly in developing countries because schools must provide each classroom with a number of electrical plugs and sockets for all students and inevitably all students must possess the devices at least with similar specification.

The implementation of MALL materials, needless to say, accommodates the existence of mobile phones in the classroom. Learning activities involving the use of mobile devices are fun for students but at the same time may create distractions. One of the participants during the interview mentioned that the use of handphone in the classroom might distract students' attention from learning and thus lead to an uncontrollable behavior. Martin \& Ertsberger (2013) found that computerbased internet group of students were less distracted than the iPad/iPod users. It might happen because students are allowed to process visual and verbal information at the same time when using mobile devices. As a result, their ability to retain information being taught in the classroom has been impaired (Norwood in Martin \& Ertsberger, 2013). Besides, one interviewee also emphasized the effectiveness of language practice instead of language materials. He pointed out that MALL materials could not make learning more authentic and thus preferred conventional textbook materials. This student's opinion is similar to the perceptions of the students in Calabrich (2016) who felt that paper-based tasks gave more contribution to their learning. 
In conclusion, the majority of the vocational school students participating in this study perceive MALL materials as useful, fun, and accommodating. Besides that, MALL materials are more accessible than traditional learning materials which can only be found at school's library. Therefore, the students can learn from anywhere and at anytime they want using an internet-equipped mobile device. Quite the opposite, some students argued that bringing mobile devices was distracting and disrupting to some extent. Mobile devices can divert students' attention from what is being taught in the classroom.

\section{CONCLUSIONS}

Digital resources have been proven able to help English language learners improve their interaction skills, widen their vocabulary range, and enhance their reading comprehension. The integration of digital technologies into an English language classroom, such as mobile devices, may contribute to collaborative and fun learning activities. Therefore, the present research was aimed to investigate vocational school students' perceptions of Mobile Assisted Language Learning (MALL) materials. Findings of this study indicate that the majority of vocational students agree that MALL materials can facilitate learning and are more accessible compared to the traditional learning materials. However, MALL materials can also create distractions in the classroom, such as diverting students' attention from the lesson.

The current study was focused on a small group of vocational students in East Java, Indonesia, and their views are not necessarily representative of Indonesian EFL students in general. However, the findings of this study have revealed that Mobile Assisted Language Learning might have a potential future in the classroom because students find it fun and highly beneficial. This study has also uncovered the fact that there are teachers who still have poor performance in utilizing digital resources in the classroom. Therefore, it is advisable for the stakeholders to consider providing teachers with training which can familiarize them with the benefits of digital technology, especially mobile devices in English language learning. Further investigation into the effect of implementing MALL materials on students' English skills may be useful in light of the ongoing efforts to face the 21 st century learning challenges.

\section{REFERENCES}

Baek, Y., Zhang, H., \& Yun, S. (2017). Teachers' Attitudes Toward Mobile Learning in Korea. TOJET: The Turkish Online Journal of Educational Technology, 16 (1), 154-163.

Burston, J. (2014). MALL: The Pedagogical Challenges. Computer Assisted Language Learning, 27(4), 344 -357. http://dx.doi.org/10.1080/09588221.2014.914539

Calabrich, S. L. (2016). Learners' perceptions of the use of mobile technology in a task-based language teaching experience. International Education Studies, 9(12), 120-136. http://dx.doi.org/10.5539/ies.v9n12p120

Dashtestani, R. (2013). Implementing Mobile-Assisted Language Learning (MALL) in an EFL context: Iranian EFL Teachers' Perspectives on Challenges and Affordances. The JALT CALL Journal, 9(2), 149-168.

Davie, N. (2015). Considerations before introducing mobile learning. Technical Report, South-Westphalia University of Applied Sciences, Meschede, Germany.

Davie, N., \& Hilber, T. (2015). Mobile-Assisted Language Learning: Students Attitudes to Using Smartphones to Learn English Vocabulary. Paper Presented in the $11^{\text {th }}$ International Conference Mobile Learning 2015.

Franklin, T. (2011). Mobile Learning: At The Tipping Point. Turkish Online Journal of Educational Technology, 10(4), 261275.

Foomani, E. M., \& Hidayati, M. (2016). A Seamless Learning Design for Mobile Assisted Language Learning: An Iranian Context. English Language Teaching, 9(5), 206-213. http://dx.doi.org/10.5539/elt.v9n5p206

Handayani, A. D., Cahyono, B. Y., Widiati, U. (2018). The use of Instagram in the teaching of EFL Writing: Effect on Writing Ability and Students' Perceptions. Studies in English Language Teaching, 6(2), 112-126.

Hockly, N. (2013). Mobile Learning. ELT Journal, 67(1), 80—84. http://dx.doi.org/10.1093/elt/ccs064

Khazaie, S., \& Ketabi, S. (2011). Contribution to Vocabulary Learning Via Mobiles. English Language Teaching, 4(1), 174184. http://dx.doi.org/10.5539/elt.v4n1p174

Kukulska-Hulme, A., \& Shield, L. (2007). Can Mobile Devices Support Collaborative Practice in Speaking and Listening. ReCALL, 271-289. http://dx.doi.org/10.1017/S0958344008000335

Martin, F., \& Ertzberger, J. (2013). Here and Now Mobile Learning: An Experimental Study on the Use of Mobile Technology. Computers \& Education, 68, 76-85. http://dx.doi.org/10.1016/j.compedu.2013.04.021

Motiwalla, L. F. (2007). Mobile Learning: A Framework and Evaluation. Computers \& Education, 49, 581—596, http://dx.doi.org/10.1016/j.compedu.2005.10.011

Patten, K. B., \& Craig, D. V. (2007). iPods and English-Language Learners: A Great Combination. Teacher Librarian, 34(5), 40- 44

Şad, S. N., \& Göktaş, O. (2013). Preservice Teachers' Perceptions about Using Mobile Phones and Laptops in Education as Mobile Learning Tools. British Journal of Educational Technology, 45, 606 - 618. http://dx.doi.org/10.1111/bjet.12064 
Sadykova, G., Gimaletdinova, G., Khalitova, L., \& Kayumova, A. (2016). Integrating Mobile Technologies into Very Young Second Language Learners' Curriculum. In S. Papadima-Sophocleous, L. Bradley \& S. Thouësny (Eds), CALL Communities and Culture - Short Papers from EUROCALL 2016 (pp. 408-412). https://doi.org/10.14705/rpnet.2016.eurocall2016.597

Saran, M., Seferoğlu, G., \& Çağıltay, K. (2009). Mobile Assisted Language Learning: English Pronunciation at Learners' Fingertips. Eurasian Journal of Educational Research, 34, 97-114.

Sato, T., Murase, F., \& Burden, T. (2015). Is Mobile-Assisted Language Learning Really Useful? An Examination of Recall Automatization and Learner Autonomy. In F. Helm, L. Bradley, M. Guarda, \& S. Thouësny (Eds), Critical CALL Proceedings of the 2015 EUROCALL Conference, Padova, Italy (pp. 495-501). http://dx.doi.org/10.14705/rpnet.2015.000382

Tayan, B. M. (2017). Students and Teachers' Perceptions into the Viability of Mobile Technology Implementation to Support Language Learning for First Year Business Students in a Middle Eastern University. International Journal of Education and Literacy Studies, 5(2),74-83. http://dx.doi.org/10.7575/aiac.ijels.v.5n.2p.74.

Van de Vyver, J. (2016). Mobile-Assisted Language Learning Community and Culture in French-Speaking Belgium: The Teachers' Perspective. In S. Papadima-Sophocleous, L. Bradley \& S. Thouësny (Eds), CALL Communities and Culture - Short Papers from EUROCALL 2016 (pp. 450 - 455). https://doi.org/10.14705/rpnet.2016.eurocall2016.605

Warschauer, M., \& Healey, D. (1998). Computers and Language Learning: An Overview. Language Teaching, 31, 57 -71. 